\title{
Heiner syndrome
}

INSERM

\section{Source}

INSERM. (1999). Orphanet: an online rare disease and orphan drug data base. Heiner syndrome. ORPHA:99932

Heiner syndrome, also called cow's milk hypersensitivity, is a food induced pulmonary hypersensiting syndrome that affects primarily infants and that is characterized by pulmonary hemosiderosis (see this term), digestive bleeding, anemia and poor growing, improving with elimination of cow's milk from the diet. 